\title{
Resistance of tomato genotypes to the silverleaf whitefly mediated by acylsugars
}

\author{
Juliano TV de Resende'; Wilson R Maluf²; Maria das Graças Cardoso²; Luciano Donizete Gonçalves³; \\ Marcos V Faria ${ }^{1}$; Ildon R do Nascimento ${ }^{1}$ \\ ${ }^{1}$ UNICENTRO-Depto. Agronomia, C. Postal 3010, 85040-080 Guarapuava-PR; ${ }^{2}$ UFLA, C. Postal 3037, 37200-000 Lavras-MG; \\ ${ }^{3}$ EPAMIG, C. Postal 295, 35901-970 Sete Lagoas-MG; jresende@unicentro.br
}

\begin{abstract}
Acylsugars in the leaflets of the wild accession LA-716 (Lycopersicon pennellii) gives resistance to Bemisia spp., which causes expressive losses to the tomato crop. The goal of this work was to evaluate the resistance to the silverleaf whitefly (Bemisia tabaci biotype B) of previously selected genotypes, based on the level of acylsugars in the leaflets. $\mathrm{F}_{2} \mathrm{BC}_{1}$ plants $\left\{\mathrm{F}_{2}[\right.$ Lycopersicon esculentum TOM 584 x (L. esculentum TOM 584 x L. pennellii LA716)]\} were selected for extreme contents of acylsugars: BPX-370B pl\#30-275, BPX-370B pl\#79-278, BPX-370B pl\#30-380, BPX-370B pl\#25-271 (high contents), BPX-370B pl\#30-02, BPX-370B pl\#30142 (low contents). These genotypes, along with the parents TOM 584 and LA-716, were submitted to a silverleaf whitefly infestation. Oviposition and nymph development were evaluated. The oviposition on the genotypes BPX-370B pl\#30-275 and BPX-370B pl\#30-380 was significantly lower to that which occurred on the genotype TOM 584 and in the other genotypes of the $\mathrm{F}_{2} \mathrm{RC}_{1}$ generation. The four genotypes selected for high acylsugar contents presented the lowest number of nymphs, except to LA-716. Although the number of eggs in the BPX-370B pl\#25-271 and BPX-370B pl\#79-278 genotypes (high contents) was elevated, the number of nymphs was reduced, similarly to the other high-acylsugar genotypes, probably due to antibioses effect.
\end{abstract}

Keywords: Bemisia tabaci biotype B, Lycopersicon esculentum, Lycopersicon pennellii, alelochemicals, plant breeding, host plant resistance.

\section{RESUMO}

Resistência de genótipos de tomateiro a Bemisia tabaci biótipo B, mediada por acilaçúcares

Acilaçúcares presentes nos folíolos do acesso selvagem 'LA716' (Lycopersicon pennellii) conferem resistência a moscas-brancas (Bemisia spp.), causadoras de danos expressivos à cultura do tomate. O objetivo do trabalho foi avaliar a resistência de genótipos de tomateiro à mosca-branca Bemisia tabaci biótipo $\mathrm{B}$, com base nos teores de acilaçúcares nos folíolos. Foram selecionadas plantas $\mathrm{F}_{2} \mathrm{RC}_{1}\{[L$. esculentum 'TOM-584' x (L. esculentum 'TOM-584' x L. pennellii 'LA-716')]\} para teores extremos de acilaçúcares: BPX-370B pl\#30-275, BPX-370B pl\#79-278, BPX-370B pl\#30-380, BPX-370B pl\#25-271 (altos teores), BPX-370B pl\#30-02, BPX-370B pl\#30-142 (baixos teores). Esses genótipos, juntamente com os parentais TOM 584 e LA-716, foram submetidos à infestação da mosca-branca. Avaliaram-se a oviposição e o desenvolvimento de ninfas. A oviposição nos genótipos BPX-370B pl\#30-275 e BPX-370B pl\#30-380 foi significativamente inferior à ocorrida em 'TOM-584' e nos demais genótipos da população $\mathrm{F}_{2} \mathrm{RC}_{1}$. Os quatro genótipos selecionados para alto teor de acilaçúcares apresentaram número de ninfas significativamente inferior aos demais, exceto ao acesso LA-716. Embora o número de ovos nos genótipos BPX-370B pl\#25-271 e BPX-370B pl\#79-278 (alto teor de acilaçúcares) tenha sido elevado, o número de ninfas foi reduzido, indicando que, mesmo havendo a oviposição sobre os folíolos, provavelmente os acilaçúcares exerceram efeito adverso ao desenvolvimento do inseto.

Palavras-chave: Lycopersicon esculentum, Lycopersicon pennellii, aleloquímicos, melhoramento vegetal, resistência a pragas.

\section{(Recebido para publicação em 18 de junho de 2008; aceito em 26 de maio de 2009)} (Received in June 18, 2008; accepted in May 26, 2009)
'LA-716' Lycopersicon penellii (Correll) with high acylsugar contents) becomes the best way to it control.

Several studies with 'LA-716' L. penelii have demonstrated high resistance levels of this access to important arthropods-pest, such as the tomato pinworm (Azevedo et al., 2003; Resende et al., 2006), whiteflies (Berlinger \& Dahan, 1984; Ponti et al., 1975; Pamplona, 2001; Resende, 2006) and mites (Resende et al., 2002; Resende, 2003). The resistance of $L$. pennellii 'LA-716' has been associated with the presence of acylsugars, which are viscous allelochemicals, composed mainly of 2,3,4-tri-O-acylated glucose esters having fatty acids with four to twelve carbon atoms (Burke et al., 1987). This phytochemical can prevent oviposition, feeding, or acting deleterious effect on the development of certain phases of arthropod pests (Goffreda et al., 1989; Shapiro et al., 1994; Resende et al., 2002; Resende et al., 2006; Goncalves et al., 2006; Resende et al., 2008).

Liedl et al. (1995) have reported a 
decrease in the adult insect population of B. Argentifolii (= B. tabaci biotype B) with the use of pulverizations on the plants prepared with purified acylsugars extracted from L. pennellii. The oviposition was also affected by the acylsugars, resulting in a smaller number of nymphs and eggs; the nymph development was not affected though.

Resende et al. (2002) and Gonçalves et al. (2006) indicate the monogenic heritance as the most probable explanation for the high levels of acylsugars in the plants, as well as the action of a recessive allele with incomplete dominance. The transferring of genes involved in the synthesis of these alelochemical compounds for commercial genotypes is one of the objectives of the tomato plant breeding concerning the resistance to the silverleaf whitefly. Therefore, in this research we aimed at studying the possible correlation between the acylsugar contents in the tomato leaflets and the resistance to the silverleaf whitefly ( $B$. tabaci biotype B) based on oviposition and occurrence of nymphs in $\mathrm{F}_{2} \mathrm{RC}_{1}$ : $=$ plants $\mathrm{F}_{2}$ [L. esculentum 'TOM-584'x (L. esculentum Mill. 'TOM-584' x $L$. pennellii 'LA716')]\} plants.

\section{MATERIAL AND METHODS}

The experiment was performed under greenhouse conditions, in Lavras, Minas Gerais State, Brazil, on October 2001. Plants of $\mathrm{F}_{2}$ (L. esculentum 'TOM-584' x L. pennellii 'LA-716') population were selected for high levels of acylsugars in the leaflets, and these were backcrossed with 'TOM 584' (recurrent parent) and self-pollinated. From the generated $\mathrm{F}_{2} \mathrm{RC}_{1}$ population, the following genotypes were selected based on acylsugar contents in the leaflets, according to the methodology described by Resende et al. (2002): BPX-370B pl\#30-275, BPX-370B pl\#79-278, BPX-370B pl\#30-380, BPX370B pl\#30-271 (selected with high level of acylsugars), BPX-370B pl\#3002, BPX-370B pl\#30-142 (selected with low levels of acylsugars).

The whiteflies for infestation were bred in tomato plants (cultivar
Santa Clara), in a greenhouse. Adults of the whitefly were identified in the entomology laboratory of the Universidade Federal de Lavras.

The selected genotypes, along with the parents 'TOM-584' and 'LA-716', used as check, comprised the eight treatments, which were evaluated in a randomized blocks design. Three clones (replications) of each of the eight genotypes were cultivated in polyethylene vases of up to five L until the pre-flowering stage and kept together for 48 hours in the greenhouse under the infestation of the silverleaf whitefly population. The leaflets sampled for oviposition evaluation were taken from the middle of the leaves placed on the higher third of each plant, according to Toscano et al. (2002), and the number of eggs per $2 \mathrm{~cm}^{2}$ of four sampled leaflets was counted, using a magnifier. Then, the plants were transferred and kept in screened cages (blocks), free of infestation. Eighteen to twenty days after the counting of eggs, samples of four expanded leaflets from the higher third of the plants were evaluated for the development of nymphs (number of nymphs in the last instar) with a magnifier. The analysis of variance (ANOVA) was performed and the means were compared through the Skott Knott test $(\mathrm{p}<0.05)$ using a SISVAR statistical package. The Pearson's correlation of the acylsugar level in the leaflets, the oviposition and the average number of silverleaf whitefly nymphs were estimated.

\section{RESULTS AND DISCUSSION}

The silverleaf whitefly oviposition in the BPX-370B pl\#30-275 and BPX$370 \mathrm{~B} \mathrm{pl} \# 30-380$ genotypes, selected for high levels of acylsugars, was significantly lower than the oviposition in the 'TOM-584' genotype and other genotypes evaluated from the $\mathrm{F}_{2} \mathrm{RC}_{1}$ population. However, the genotypes also selected for high levels of acylsugars (BPX-370B pl\#25-271 and BPX-370B $\mathrm{pl}$ \#79-278) presented high levels of oviposition, similar to that observed in TOM-584 and the genotypes with low levels of acylsugars (BPX-370B pl\#30-02 and BPX-370B pl\#30-142). A low and non-significant value for the correlation between the levels of acylsugars and silverleaf whitefly oviposition $(\mathrm{r}=-0,36)$ was observed (Table 1).

Maciel (2008) and Silva (2009) reported that genotypes selected for high levels of acylsugars, obtained from the same crossing of this work, showed low levels of $B$. tabaci biotype $B$ oviposition. These results were not significant enough to claim that there is not a preference for oviposition in the genotypes with high levels of acylsugars. However, Pamplona (2001) evaluated the oviposition of $B$. tabaci on genotypes of a $\mathrm{F}_{2}$ (L. esculentum 'TOM-584' x L. pennellii 'LA-716') population and reported an evident action of acylsugars upon the whitefly in the genotypes with high contents of this substance because the insects were trapped in the exudates and died without ovipositing. The author related the non preference type for oviposition both in confined and free choice experiments and the association of the high acylsugars contents to the density of type IV trichomes.

The average number of nymphs was significantly higher in the two $\mathrm{F}_{2} \mathrm{RC}_{1}$ genotypes with a low level of acylsugars than in the four ones with a high level of acylsugars. In all the low acylsugars level genotypes (BPX-370B pl\#30-02

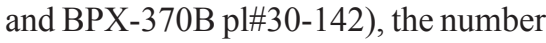
of nymphs was similar to the susceptible check (TOM-584). On the other hand, in the four $\mathrm{F}_{2} \mathrm{RC}_{1}$ genotypes with high levels of acylsugars, the number of nymphs was lower than in the other treatments, except for $L$. pennellii 'LA 716'. Unlike what happened with the oviposition, the average number of nymphs per leaflet was negatively and significantly $(\mathrm{r}=-0,94)$ correlated with the acylsugar level in the leaflets (Table 1). Selection of the genotypes was only based on the acylsugars levels in the leaflets, although viscosity and other factors (not yet identified) present in LA-716 can contribute to the resistance. Nevertheless, some of these additional factors were not incorporated (or selected) in the improved genotypes from backcross generation, which explain 
Table 1. Acylsugar levels in the leaflets, average number of eggs and nymphs, and their Pearson's correlations, involving eight tomato plant genotypes selected for extreme levels of acylsugars in the leaflets (níveis de acilaçúcares nos folíolos, número médio de ninfas e de ovos, e suas correlações de Pearson, envolvendo oito genótipos de tomateiro selecionados para níveis extremos de acilaçúcares nos folíolos). Lavras, UFLA, 2001.

\begin{tabular}{|c|c|c|c|}
\hline Genotype & $\begin{array}{l}\text { Acylsugar level } \\
\left(\text { (nmol cm } \text { cm }^{-2}\right.\end{array}$ & $\begin{array}{l}\text { Average number of eggs } \\
\text { (per } 2 \mathrm{~cm}^{2} \text { of leaflet) }\end{array}$ & $\begin{array}{c}\text { Average number of nymphs } \\
\text { (per leaflet) }\end{array}$ \\
\hline BPX-370Bpl\#30-142 (=Low 1) & $4.7 \pm 0.8 \mathrm{~b}$ & $66.7 \pm 6.2 \mathrm{c}$ & $115.1 \pm 4.8 \mathrm{c}$ \\
\hline BPX-370Bpl\#30-02 (=Low 2) & $4.9 \pm 1.1 \mathrm{~b}$ & $88.6 \pm 5.6 \mathrm{c}$ & $155.5 \pm 7.3 \mathrm{c}$ \\
\hline TOM-584 (=Low) & $7.5 \pm 1.3 \mathrm{~b}$ & $131.7 \pm 9.2 \mathrm{c}$ & $154.3 \pm 6.9 \mathrm{c}$ \\
\hline LA716 (=High) & $32.5 \pm 5.8 \mathrm{a}$ & $0 \mathrm{a}$ & $0.1 \mathrm{a}$ \\
\hline BPX-370Bpl\#25-271 (=High 1) & $36.4 \pm 7.2 \mathrm{a}$ & $110.3 \pm 4.6 \mathrm{c}$ & $66.1 \pm 3.1 \mathrm{~b}$ \\
\hline BPX-370Bpl\#30-380 (=High 2) & $38.2 \pm 5.4 \mathrm{a}$ & $30.7 \pm 3.3 \mathrm{~b}$ & $60.6 \pm 5.7 \mathrm{~b}$ \\
\hline BPX-370Bpl\#79-278 (=High 3) & $40.1 \pm 8.1 \mathrm{a}$ & $108.6 \pm 7.0 \mathrm{c}$ & $51.6 \pm 3.6 \mathrm{~b}$ \\
\hline BPX-370Bpl\#30-275 (=High 4) & $43.2 \pm 5.6 \mathrm{a}$ & $38.5 \pm 4.5 \mathrm{~b}$ & $31.1 \pm 7.3 \mathrm{~b}$ \\
\hline Linear correlations $(\mathrm{r})$ : & & $-0.36^{\mathrm{ns}}$ & $-0.94 * *$ \\
\hline
\end{tabular}

*Means followed by the same letter in the columns do not differ according to the Skott Knott test ( $<<0.05)$ (médias seguidas das mesmas

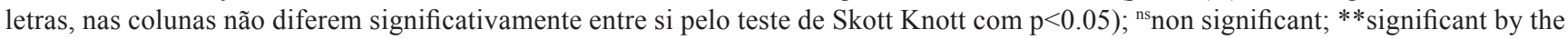
F test at $1 \%$.

the differences in resistance among LA-716 and high acylsugars selected genotypes from $\mathrm{F}_{2} \mathrm{RC}_{1}$. Many studies have associated tomato pests resistance to trichomes present in leaflets, related to changes in oviposition and survival of whitefly nymphs. Vendramim et al. (2009) related that oviposition of $B$. tabaci biotype $\mathrm{B}$ was concentrated near to non glandular trichomes. On the other hand, Gonçalves et al. (2007) verified that acylsugars levels were correlated with neither glandular nor non-glandular trichome densities.

The $L$ pennellii 'LA-716' resistance to the silverleaf whitefly, which is attributed to the acylsugars in the literature (Goffreda et al., 1989), was confirmed by Freitas et al. (2002); Maciel (2008); Pereira et al. (2008) and Silva (2009). Liedl et al. (1995) reported that acylsugars applications, extracted from the LA-716 accession and pulverized on the L. esculentum plants reduced oviposition and the number of nymphs of $B$. tabaci biotype B.

The negative correlation between the acylsugars levels in the leaflets and the number of nymphs of $B$. tabaci biotype $\mathrm{B}$ in the last instar was high $(\mathrm{r}=-0,94)$, indicating that the indirect selection of genotypes with high levels of acylsugars in the leaflets leads to the repression of the silverleaf whitefly nymph development (Table 1).
Maciel (2008) reported that tomato hybrids obtained through the crossing of contrasting lines for acylsugars contents (low x high levels) presented fewer oviposition and lower survival of silverleaf whitefly nymphs than lines with low levels of acylsugars and these parameters do not differ from high levels of acylsugars lines. Silva (2009) reported that both oviposition and survival of nymphs of $B$. argentifolii (=B. tabaci biotype B) were reduced by the presence of high acylsugars contents in tomato genotypes, especially when compared to control with low acylsugars levels (the commercial hybrid Débora Max and the experimental line TOM 684).

This research shows that acylsugars are responsible for resistance of tomato to B. tabaci biotype B. So, these genotypes selected with high levels of this alelochemical are promising in breeding programs, aiming through backcrossing to obtain advanced lines that could be used to obtain hybrids.

\section{REFERENCES}

AZEVEDO SM; FARIA MV; MALUF WR; OLIVEIRA ACB; FREITAS JA. 2003. Zingiberene-mediated resistance to the South American tomato pinworm. Euphytica 134: 347-351.

BERLINGER MJ; DAHAN R. 1984. Resistance to the tobacco whitefly Bemisia tabaci, in tomato and related species: a quick screening method. Bull. IOBC/WPRS 39-40.

BURKE AB; GOLDSBY G; MUDD JB. 1987. Polar epicuticular lipids on Lycopersicon pennellii. Phytochemistry 26: 2567-2571.

DUFFUS JE. 1996. Whifetly: Borne viruses. In: GERLING D; MAYER RT (eds). Bemisia: 1995: taxonomy, biology, damage, control and management. Andover: Intercept. p.255-264.

FREITAS JA; MALUF WR; CARDOSO MG; GOMES LAA; BEARZOTTI E. 2002. Inheritance of foliar zingiberene contents and their relationship to trichome densities and silverleaf whitefly resistance in tomatoes. Euphytica 127: 275-287.

GOFFREDA JC; MUTSHLER MA; AVÉ DA; TINGEY WA; STEFFENS JC. 1989. Aphid deterrence by glucose esters in glandular trichome exudate of wild tomato, Lycopersicon pennellii. Journal of Chemical Ecology 15: 2135-2147.

GONÇALVES LD, MALUF WR; CARDOSO MG; RESENDE JTV; CASTRO EM; SANTOS NM; NASCIMENTO IR; FARIA MF. 2006. Zingibereno, tricomas foliares e sua ação na repelência a Tetranychus evansi em tomateiros derivados do cruzamento Lycopersicon esculentum $\mathrm{x}$ L. hirsutum var. hirsutum. Pesquisa Agropecuária Brasileira 41: 267-273.

GONÇALVES LD, MALUF WR; CARDOSO MG; GOMES LAA; NASCIMENTO IR. 2007. Herança de acilaçúcares em genótipos de tomateiro provenientes de cruzamento interespecífico. Pesquisa Agropecuária Brasileira 42: 699-705.

LIEDL BE; LAWSON DM; WHITE KK; SHAPIRO JA; COHEN DE; CARSON WG; TRUMBLE JT; MUTSCHLER MA. 1995. Acylsugars of wild tomato Lycopersicon pennellii alters settling and reduces oviposition of Bemisia argentifolii (Homoptera: Aleyrodidae). Journal of Economic Entomology 88: 742-748.

MACIEL GM. 2008. Broad spectrum arthropod 
resistance mediated by leaf acylsugar contents in tomatoes. Lavras: UFLA. 34p (Tese mestrado).

OLIVEIRA MRV; HENNEBERRY TJ; ANDERSON P. 2001. History, current status, and collaborative research projects for Bemisia tabaci. Crop Protection 20: 709-723.

PAMPLONA AMSR. 2001. Avaliação de genótipos de tomate Lycopersicon ssp. com diferentes concentrações de acilaçúcares, quanto à resistência a Bemisia tabaci (Gennadius, 1889) (Hemitera: Aleyrodidae). Lavras: UFLA. 70p (Tese mestrado).

PEREIRA GVN; MALUF WR; SANTOS CD; GONÇALVES LD; NASCIMENTO IR; GOMES LAA; LICURSI V. 2008. Seleção para alto teor de acilaçúcares em genótipos de tomateiro e sua relação com a resistência ao ácaro vermelho (Tetranychus evansi) e a traça (Tuta absoluta). Ciência e Agrotecnologia 32: 996-1004.

PONTI OMB; PET G; HOGENBOOM NG 1975. Resistance to the glasshouse silverleaf whitefly
(Trialeurodes vaporariorum Westw) in tomato (Lycopersicon esculentum Mill) and related species. Euphytica 24: 645-649.

RESENDE JTV; CARDOSO MG; MALUF WR; SANTOS CD; GONÇALVES LD; RESENDE LV; NAVES FO. 2002. Método colorimétrico para quantificação de acilaçúcar em genótipos de tomateiro. Ciência e Agrotecnologia 26: 1204-1208.

RESENDE JTV; MALUF WR; FARIA MV; PFANN AZ; NASCIMENTO IR. 2006. Acylsugars in tomato leaflets confer resistance to the South American tomato pinworm, Tuta absoluta Meyr. Scientia Agricola 63: 20-25.

RESENDE JTV; MALUF WR; CARDOSO MG; FARIA MV; GONCALVES LD; NASCIMENTO IR. 2008. Resistance of tomato genotypes with high level of acylsugars to Tetranychus evansi Baker \& Pritchard. Scientia Agricola 65: 31-35.

RESENDE JTV. 2003. Resistência a artrópodospragas, mediada por acilaçúcares em tomateiros obtidos do cruzamento interespecifico de
Lycopersicon esculentum Mill 'TOM-584' $x$ L. pennellii 'LA-716'. Lavras: UFLA. 91p (Tese doutorado).

SHAPIRO JA; STEFFENS JC; MUTSCHLER MA. 1994. Acylsugars of the wild tomato Lycopersicon pennellii in relation to geographic distribution of the species. Biochemical Systematics and Ecology 22: 545-561.

SILVA VF. 2009. Resistência a artrópodospraga em genótipos de tomateiro ricos em zingibereno elou acilaçúcares. Lavras: UFLA. $63 \mathrm{p}$ (Tese doutorado).

TOSCANO LC; BOIÇA JUNIOR AL; MARUYAMA WI. 2002. Fatores que afetam a oviposição de Bemisia tabaci (Genn.) biótipo B (Hemiptera: Aleyrodidae) em tomateiro. Neotropical Entomology 31: 631-634.

VENDRAMIM JD; SOUZA AP; ONGARELLI MG. 2009. Comportamento de oviposicão da mosca-branca Bemisia tabaci (Genn.) (Hemiptera: Aleyrodidae) biótipo B em tomateiro. Neotropical Entomology 38: 126-132. 